University of Nebraska - Lincoln

DigitalCommons@University of Nebraska - Lincoln

USDA Systematic Entomology Laboratory

Entomology Collections, Miscellaneous

2007

\title{
Vouchering DNA-Barcoded Specimens: Test of a Nondestructive Extraction Protocol for Terrestrial Arthropods
}

\author{
Daniel L. Rowley \\ United States Department of Agriculture, Agricultural Research Service, Insect Biocontrol Laboratory, Bldg. \\ 011 A, Room 214, BARC-West, Beltsville, Maryland 20705, USA \\ Jonathan A. Coddington \\ Smithsonian Institution, National Museum of Natural History, Washington, D.C., USA \\ Michael W. Gates \\ United States Department of Agriculture, Agricultural Research Service, Systematic Entomology \\ Laboratory, Beltsville, Maryland, USA \\ Allen L. Norrbom \\ United States Department of Agriculture, Agricultural Research Service, Systematic Entomology \\ Laboratory, Beltsville, Maryland, USA \\ Ronald A. Ochoa \\ United States Department of Agriculture, Agricultural Research Service, Systematic Entomology \\ Laboratory, Beltsville, Maryland, USA \\ Seetow nextpage for additional authors and adtional works at:https://digitalcommons.unl.edu/systentomologyusda \\ Part of the Entomology Commons
}

Rowley, Daniel L.; Coddington, Jonathan A.; Gates, Michael W.; Norrbom, Allen L.; Ochoa, Ronald A.; Vandenberg, Natalia J.; and Greenstone, Matthew H., "Vouchering DNA-Barcoded Specimens: Test of a Nondestructive Extraction Protocol for Terrestrial Arthropods" (2007). USDA Systematic Entomology Laboratory. 38.

https://digitalcommons.unl.edu/systentomologyusda/38

This Article is brought to you for free and open access by the Entomology Collections, Miscellaneous at DigitalCommons@University of Nebraska - Lincoln. It has been accepted for inclusion in USDA Systematic Entomology Laboratory by an authorized administrator of DigitalCommons@University of Nebraska - Lincoln. 


\section{Authors}

Daniel L. Rowley, Jonathan A. Coddington, Michael W. Gates, Allen L. Norrbom, Ronald A. Ochoa, Natalia J. Vandenberg, and Matthew H. Greenstone 
BARCODING ARTICLE

\title{
Vouchering DNA-barcoded specimens: test of a nondestructive extraction protocol for terrestrial arthropods
}

\author{
DANIEL L. ROWLEY,$*$ JONATHAN A. CODDINGTON, $§$ MICHAEL W. GATES, $₫ \S$

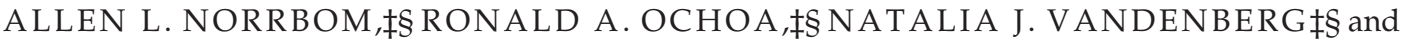 \\ MATTHEW H. GREENSTONE* \\ *United States Department of Agriculture, Agricultural Research Service, Insect Biocontrol Laboratory, Bldg. 011 A, Room 214, \\ BARC-West, Beltsville, Maryland 20705, USA, +Smithsonian Institution, National Museum of Natural History, Washington, D.C., \\ USA, ‡United States Department of Agriculture, Agricultural Research Service, Systematic Entomology Laboratory, Beltsville, \\ Maryland, USA
}

\begin{abstract}
Morphology-based keys support accurate identification of many taxa. However, identification can be difficult for taxa that are either not well studied, very small, members of cryptic species complexes, or represented by immature stages. For such cases, DNA barcodes may provide diagnostic characters. Ecologists and evolutionary biologists deposit museum vouchers to document the species studied in their research. If DNA barcodes are to be used for identification, then both the DNA and the specimen from which it was extracted should be vouchered. We describe a protocol for the nondestructive extraction of DNA from terrestrial arthropods, using as examples members of the orders Acarina, Araneae, Coleoptera, Diptera, and Hymenoptera chosen to represent the ranges in size, overall sclerotization, and delicacy of key morphological characters in the group. We successfully extracted sequenceable DNA from all species after 1-4 h of immersion in extraction buffer. The extracted carcasses, processed and imaged using protocols standard for the taxon, were distinguishable from closely related species, and adequate as morphological vouchers. We provide links from the carcasses and DNA vouchers to image (MorphBank) and sequence (GenBank) databases.
\end{abstract}

Keywords: Acarina, Arachnida, barcode, cytochrome oxidase I, Insecta, mitochondrial DNA, voucher

Received 6 January 2007; revision accepted 11 June 2007

\section{Introduction}

The correct identification of species is essential to the performance of ecological and evolutionary research. Morphology-based keys support accurate identification of many taxa. However, for taxa that are not well studied, or for which distinguishing morphological characters have not been discerned, identification can be difficult. Accurate identification is especially problematic for very small organisms, for members of cryptic species complexes, and for eggs and other immature stages (Toft 1983; Cockburn 1990; Sperling \& Hickey 1994; Brunner et al. 2002; Chen et al. 2002; Armstrong \& Ball 2005; Ball et al. 2005;

Correspondence: Matthew H. Greenstone, Fax: 301504 5104; E-mail: greenstm@ba.ars.usda.gov

§These authors contributed equally to this research.
Greenstone et al. 2005; Barber \& Boyce 2006; Grosjean et al. 2006). For such situations, species-specific fragments of DNA, known as DNA barcodes (Hebert et al. 2002), may provide a new source of characters for species-level identification.

Besides providing new characters for hitherto poorly known groups, the study of DNA sequence data has enabled new insights into the ecology and phylogenetic relationships of well-studied taxa, including the largest phylum of organisms, Arthropoda (e.g. Paskewitz \& Collins 1990; Brower 1999; Anderson et al. 2000; Gleeson et al. 2000; Wells \& Sperling 2001; Brunner et al. 2002; Chen et al. 2002, 2006; Jarman et al. 2002; Besansky et al. 2003; Ball et al. 2005; Barrett \& Hebert 2005; Greenstone et al. 2005, 2007; Hogg \& Hebert 2005; Mitchell et al. 2005; Monoghan et al. 2005; Ball \& Armstrong 2006; Barber \& Boyce 2006; Greenstone 2006; Hajibabael et al. 2006; Kaila \& Ståhls 2006). An important 
part of this enterprise is the deposition of sequences into publicly accessible sequence databases, the most comprehensive of which is GenBank (Benson et al. 2007). However, GenBank contains numerous errors, some of which are due to misidentification of the species whose DNA has been sequenced (Harris 2003; Vigalys 2003). Ecologists and evolutionary biologists routinely deposit museum specimens, referred to as vouchers, to document the species studied in their research (Thomas 1994). If DNA barcodes are to be used for identification, then the DNA as well as the specimen from which it was extracted should be vouchered (Hafner 1994). This would make it possible to determine whether the organism from which the DNA was extracted had been correctly identified in the first place.

Unfortunately, many protocols for DNA extraction, especially for small specimens, require crushing of the entire sample, precluding deposition of the carcass as a museum voucher (Whitfield \& Cameron 1994). One suggested approach is to take multiple images of the specimen before crushing (De Ley et al. 2005). Another approach, for sufficiently large, bilaterally symmetric animals, is to remove a single appendage for DNA extraction (Starks \& Peters 2002). However, if there are appendage-specific characters essential for species identification, subsequent loss of the remaining appendage of the pair, during shipment or routine examination, would render the rest of the specimen useless as a voucher. Alternatively, the removed appendage, if essentially intact, could be curated with the rest of the specimen, but this is tedious and introduces opportunities for mix-ups.

Here we present and evaluate a protocol for the nondestructive extraction of mitochondrial DNA from terrestrial arthropods, using as our subjects a variety of animals chosen to be representative of the ranges in size, overall sclerotization, and delicacy of key morphological characters in this diverse group. On the basis of our intimate knowledge of their systematics and taxonomy, we selected five species from two arachnid and three insect orders of great ecological significance in terrestrial ecosystems.

\section{Materials and methods}

\section{Taxa}

Tenuipalpidae is a cosmopolitan mite family comprising more than 800 phytophagous species in 32 genera. Because they are small $(200-300 \mu \mathrm{m})$, slow moving, and exhibit cryptic colouration and stationary behaviour, tenuipalpids are very difficult to recognize, collect, and identify in the field (Jeppson et al. 1975). Having another tool to help distinguish closely related species is therefore of utmost importance. The red palm mite, Raoiella indica Hirst (Acari: Tenuipalpidae), is a new invasive pest in the Americas that infests coconuts, bananas, and several ornamental plants
(Flechtmann \& Etienne 2004). Raoiella contains several species that are not well known or are poorly described. The genus is defined by the shape of the dorsal setae; $R$. indica is distinguished from its congeners by the size of the dorsal setae.

The basilica spider, Mecynogea lemniscata (Walckenaer) (Araneae: Araneidae), belongs to a New World genus comprising about a dozen species (Levi 1980; Platnick 2006); as with spiders generally, congeners are distinguished primarily on the basis of subtle morphological differences in the genitalia.

The pink ladybug, Coleomegilla maculata (De Geer) (Coleoptera: Coccinellidae), is a common denizen of row crops in eastern North America; the genus is restricted to the New World and is most diverse in the tropics and subtropics. The limits between Coleomegilla and the related genera Naemia, Paranaemia and Eumegilla are in need of clarification and the subject of a forthcoming revision (N.J.V., J. Obrycki, J.A. Giorgi, and W. Steiner, in progress). Genitalia and colour patterns in this group are conservative, and often appear very similar among related taxa. Naemia can generally be recognized by the fact that the elytral spots are connected longitudinally, but some specimens from the northern and southern limits of the range have disconnected spots and may be mistaken for Coleomegilla (see Fig. 3C). These look-alikes are most easily separated by the form of the tarsal claw, simple and scythelike in Naemia (Fig. 3F) but bearing a large quadrate tooth in Coleomegilla (Fig. 3D, E).

Delphinia picta (Fabricius) (Diptera: Ulidiidae) is a ubiquitous saprophage in eastern North America with larvae that feed primarily on decaying vegetation. Ulidiids are closely related to fruit flies (Tephritidae), a group that includes numerous agricultural pests, and the key characters for distinguishing species within both families are similar. These include wing patterns, body colour patterns, number and positions of setae (chaetotaxy), microtrichia patterns, and genitalic morphology.

Eurytoma rhois Crosby (Hymenoptera: Eurytomidae) belongs to the most commonly collected genus of the family Eurytomidae (Hymenoptera), a cosmopolitan family of phytophagous and entomophagous parasitic wasps. The key diagnostic features for E. rhois concern relative sizes of sclerites and the propodeal surface sculpture.

\section{Collection of arthropods}

A variety of methods, some of them taxon-specific, are used to collect and preserve terrestrial arthropods (US Department of Agriculture 1986; Aguiar \& Sharkov 1997; Noyes 1998; Triplehorn \& Johnson 2004). Because all specimens were to be extracted in an aqueous buffer, all were collected into $\mathrm{EtOH}$, regardless of customary methods of preservation for the taxon. We selected an $\mathrm{EtOH}$ 
concentration of $80 \%$ as sufficiently high to preserve DNA but not so high as to cause desiccation that would unduly distort the animal's external morphology. The collectors, localities, and geopositioning coordinates for all specimens are given in Table 1.

\section{DNA extraction protocol}

Each specimen was removed from the $80 \%$ EtOH, allowed to air dry, and placed in a $1.5-\mathrm{mL}$ microfuge tube with forceps that had been soaked in $0.5 \% \mathrm{NaCIO}$. Depending upon the size of the specimen, 100,200 , or $400 \mu \mathrm{L}$ of a GuSCN-based extraction buffer, originally developed to extract DNA from mammalian teeth and bones (Rohland et al. 2004), was added to the tube, which was then placed in a $60^{\circ} \mathrm{C}$ water bath for 1,2 , or $4 \mathrm{~h}$. The extraction buffer was removed to a clean tube and the DNA was precipitated by addition of a volume of isopropanol equal to the volume of the extraction buffer in which the specimen had been incubated. The sample was stored overnight at $-20^{\circ} \mathrm{C}$ and centrifuged at $4{ }^{\circ} \mathrm{C}$ for $20 \mathrm{~min}$ at $13000 \mathrm{~g}$. After a single rinse in $70 \% \mathrm{EtOH}$, the DNA was vacuum-dried, resuspended in a volume of $0.1 \times \mathrm{TE} \mathrm{pH} 8.0$ equal to that of the extraction buffer, and stored at $-20^{\circ} \mathrm{C}$. Four individuals of each taxon were subjected to each extraction interval, and two were used as controls that went through all procedures except extraction. Two additional DNA samples of each species, extracted by conventional means from whole-body homogenates (Greenstone et al. 2005), were provided for reference.

Following extraction, the extracted arthropod carcasses and unextracted controls were again immersed in $80 \%$ EtOH and stored at $4{ }^{\circ} \mathrm{C}$ until prepared for imaging.

\section{PCR and sequencing}

Polymerase chain reaction (PCR) conditions and components were as described in Greenstone et al. (2005), with 5-6 $\mu \mathrm{L}$ of the DNA extract used in the reaction. DNA of all species was amplified with cytochrome oxidase I (COI) primers C1-J-1751and C1-N-2191, as well as C1-J-2195 and C1N-2568 (Simon et al. 1994), with expected amplicon sizes of 488 and $421 \mathrm{bp}$, respectively. Mecynogea DNA was additionally amplified with COI primer pairs C1-J-1751 'SPID' (Hedin \& Maddison 2001) and C1-N-2776 (Simon et al. 1994), with an expected amplicon size of $1070 \mathrm{bp}$, to ensure complete coverage of the sequence. The Raoiella samples required a preliminary round of amplification utilizing a GenomiPhi kit (GE Healthcare) in order to obtain sufficient amplification product for sequencing.

Amplified DNA was visualized by electrophoresis of $6 \mu \mathrm{L}$ of the PCR/stop reaction $(12 \mu \mathrm{L}$ for Raioella and Eurytoma because $6 \mu \mathrm{L}$ did not image well) in 1.5\% agarose. The remainder of the reaction mixture was loaded, electro- phoresed in $1.5 \%$ NuSieve agarose (Cambrex Bio Science) in $1 \times$ TAE modified to have a final EDTA concentration of $0.1 \mathrm{~mm}$, and the fragments excised for sequencing by BigDye terminator version 3.1 kits on an $\mathrm{ABI} 3100$ sequencer (Applied Biosystems). Editing was performed with Lasergene (DNAStar).

\section{Imaging of extracted carcasses}

Arthropod carcasses were processed and imaged after DNA extraction using protocols standard for the taxon. Carcasses of $R$. indica were slide-mounted and viewed by Nomarski interference. Carcasses of M. lemniscata were photographed in $\mathrm{EtOH}$ under a dissecting microscope. Carcasses of C. maculata were removed from the $\mathrm{EtOH}$ and point-mounted; scanning electron microscope (SEM) images of the tarsi were made from coated specimens mounted on stubs. D. picta carcasses were removed from $\mathrm{EtOH}$ and dried for $48 \mathrm{~h}$ in ethyl acetate, then air-dried or criticalpoint-dried, mounted on pins, and imaged by light microscopy. Wings of several specimens were removed and slide-mounted in Euparal. Carcasses of E. rhois were removed from the $\mathrm{EtOH}$ and dehydrated using HMDS (Heraty \& Hawks 1998); dried specimens were carefully disarticulated prior to imaging via SEM.

For SEM imaging, specimens were affixed to $12.7 \times 3.2 \mathrm{~mm}$ Leica/Cambridge aluminium SEM stubs with carbon adhesive tabs (Electron Microscopy Sciences no. 77825-12). Stub-mounted specimens were sputter-coated using a Cressington Scientific 108 Auto with a gold-palladium mixture from at least three different angles to ensure complete coverage ( 20-30 nm coating). SEM images were taken with an Amray 1810 with $\mathrm{LaB}_{6}$ source (Amray).

\section{Deposition of morphological vouchers, specimen images, DNA vouchers, and DNA sequences}

Extracted arthropod carcasses were deposited as morphological vouchers, prepared according to standard museum practices, in the Insect and Mite National Collection of the Smithsonian Institution, National Museum of Natural History (NMNHENTM) in Washington, D.C.; the companion DNA samples were deposited in the NMNHENTM Tissue Collection. Accession numbers for both carcasses and DNA are provided in Table 1. DNA sequences were deposited in GenBank and images in MorphBank; their accession numbers are also given in Table 1.

\section{Results and discussion}

When the GuSCN-based buffer we used was employed to extract DNA from vertebrate teeth and bones, it did not affect the appearance of the specimens, other than to cause them to 'appear a little cleaner' (Rohland et al. 2004). Its 
918 BARCODING ARTICLE

Table 1 Data for animals used in the study. Delphinia picta were collected in fruit fly traps and Eurytoma rhois by sweeping; all other species were collected by hand. All localities are in the USA unless noted otherwise

\begin{tabular}{|c|c|c|c|c|c|c|}
\hline \multirow[b]{2}{*}{ Taxon } & \multirow{2}{*}{$\begin{array}{l}\text { DNA } \\
\text { extraction } \\
\text { treatment }\end{array}$} & \multirow{2}{*}{$\begin{array}{l}\text { MorphBank } \\
\text { no. }\end{array}$} & \multicolumn{2}{|c|}{ NMNH-ENTM no. } & \multirow{2}{*}{$\begin{array}{l}\text { GenBank } \\
\text { no. }\end{array}$} & \multirow{2}{*}{$\begin{array}{l}\text { Locality, habitat, collection dates, } \\
\text { collectors, and GPS coordinates }\end{array}$} \\
\hline & & & Carcass & DNA & & \\
\hline Raoiella indica & 4-h GuSCN & 137781, 137782 & 00530938 & 00530920 & EF185151 & Saint Lucia, West Indies, Castries \\
\hline Hirst (ACARI: & Conventional & & & 00530918 & EF185151 & On coconut palm (Cocos nucifera) \\
\hline \multirow[t]{2}{*}{ Tenuipalpidae) } & Conventional & & & 00530919 & EF185151 & 10 September 2005; Coll.: R. Ochoa \& \\
\hline & None & 137780 & 00530939 & & & G. Mathurian 13.900000; 60.833333 \\
\hline Mecynogea & 2-h GuSCN & & 00447378 & 00530922 & EF185153 & Maryland, Howard CO, Ellicott City \\
\hline $\begin{array}{l}\text { lemniscata } \\
\text { (Walckenaer) }\end{array}$ & 2-h GuSCN & & 00447379 & 00530923 & EF577426 & Understorey of deciduous forest remnant \\
\hline Araneae: & 4-h GuSCN & 137705 & 00447380 & 00530924 & DQ029239 & 22 July 2006; Coll.: A. Greenstone \& \\
\hline \multirow[t]{4}{*}{ Araneidae } & 4-h GuSCN & & 00447381 & 00530925 & EF185152 & M. Greenstone \\
\hline & Conventional & & & 00530910 & DQ029238 & $39.230236 ; 76.823228$ \\
\hline & Conventional & & & 00530911 & DQ029239 & \\
\hline & None & 137703 & 00447382 & & & \\
\hline Delphinia picta & 2-h GuSCN & 137793 & 00529373 & 00530921 & EF185150 & Georgia, Dekalb CO, Atlanta, \\
\hline (Fabricius) & 1-h GuSCN & 137788 & 00530935 & 00530940 & EF185150 & 3310 Buford Highway \\
\hline Diptera: & 4-h GuSCN & 137789 & 00530936 & 00530941 & EF185150 & May 2005; Coll.: J. Orr \\
\hline \multirow[t]{4}{*}{ Ulidiidae } & None & 137791 & 00530937 & & & $33.834931 ; 84.318761$ \\
\hline & Conventional & & & 00530912 & EF185150 & \\
\hline & Conventional & & & 00530913 & EF185150 & \\
\hline & NONE & 137795 & 00529374 & & & \\
\hline Coleomegilla & 1-h GuSCN & & 00529370 & 00530926 & EF192134 & Maryland, Prince Georges CO, Beltsville \\
\hline $\begin{array}{l}\text { maculata } \\
\text { (De Geer) }\end{array}$ & 1-h GuSCN & & 00529371 & 00530927 & EF192134 & $\begin{array}{l}\text { Laboratory colony, originally from } \\
\text { potato fields }\end{array}$ \\
\hline Coleoptera: & 1-h GuSCN & & 00529376 & 00530928 & EF192134 & 20 June 2003; Coll.: M. Greenstone \\
\hline \multirow[t]{7}{*}{ Coccinellidae } & 2-h GuSCN & 137837 & 00529372 & 00530929 & EF192134 & $39.033333 ; 76.927500$ \\
\hline & 1-h GuSCN & 137868 & 00530976 & & & \\
\hline & None & 137869 & 00529369 & & & \\
\hline & None & 137834 & 00530968 & & & \\
\hline & Conventional & & & 00530934 & EF192134 & Maryland, Prince Georges CO, Beltsville \\
\hline & Conventional & & & 00530914 & EF192134 & Potato fields \\
\hline & & & & & & $\begin{array}{l}3 \text { July 2005; Coll.: D. Rowley \& M. Greenstone } \\
\text { 39.033333; 76.927500 }\end{array}$ \\
\hline Naemia sp. & None & 137827 & 00529379 & & & Nova Scotia, Canada, Granville Beach \\
\hline Coleoptera: & & & & & & On Spartina sp. \\
\hline Coccinellidae & & & & & & $\begin{array}{l}6 \text { August 2006; Coll.: C.Majka \& B. Maybank. } \\
44.752031 ; 65.520858\end{array}$ \\
\hline $\begin{array}{l}\text { Naemia seriata } \\
\text { (Melsheimer) }\end{array}$ & None & 137860 & 00529380 & & & Maryland, Talbot Georges CO, Wittman \\
\hline \multirow{3}{*}{$\begin{array}{l}\text { Coleoptera: } \\
\text { Coccinellidae }\end{array}$} & & & & & & On Spartina sp. \\
\hline & & & & & & \\
\hline & & & & & & $\begin{array}{l}24 \text { July 2005; Coll.: W. E. Steiner } \\
38.800000 ; 76.283333\end{array}$ \\
\hline \multirow{7}{*}{$\begin{array}{l}\text { Eurytoma } \\
\text { rhois Crosby } \\
\text { Hymenoptera: } \\
\text { Eurytomidae }\end{array}$} & 2-h GuSCN & 135296-135299 & 00529377 & 00530930 & EF185155 & Rhode Island, Kent CO, Warwick \\
\hline & 4-h GuSCN & & & 00530931 & EF185156 & Powerline right-of-way at junction \\
\hline & 4-h GuSCN & & & 00530932 & EF185157 & of Route 117 and Toll Gate Road \\
\hline & 4-h GuSCN & & & 00530933 & EF185157 & On blooming Rhus copallina \\
\hline & Conventional & & & 00530916 & EF185154 & 25 July, 2006; Coll.: C. Gates \\
\hline & Conventional & & & 00530917 & EF577427 & $41.701919 ; 71.487636$ \\
\hline & None & 135292-135295 & 00529378 & & & \\
\hline
\end{tabular}



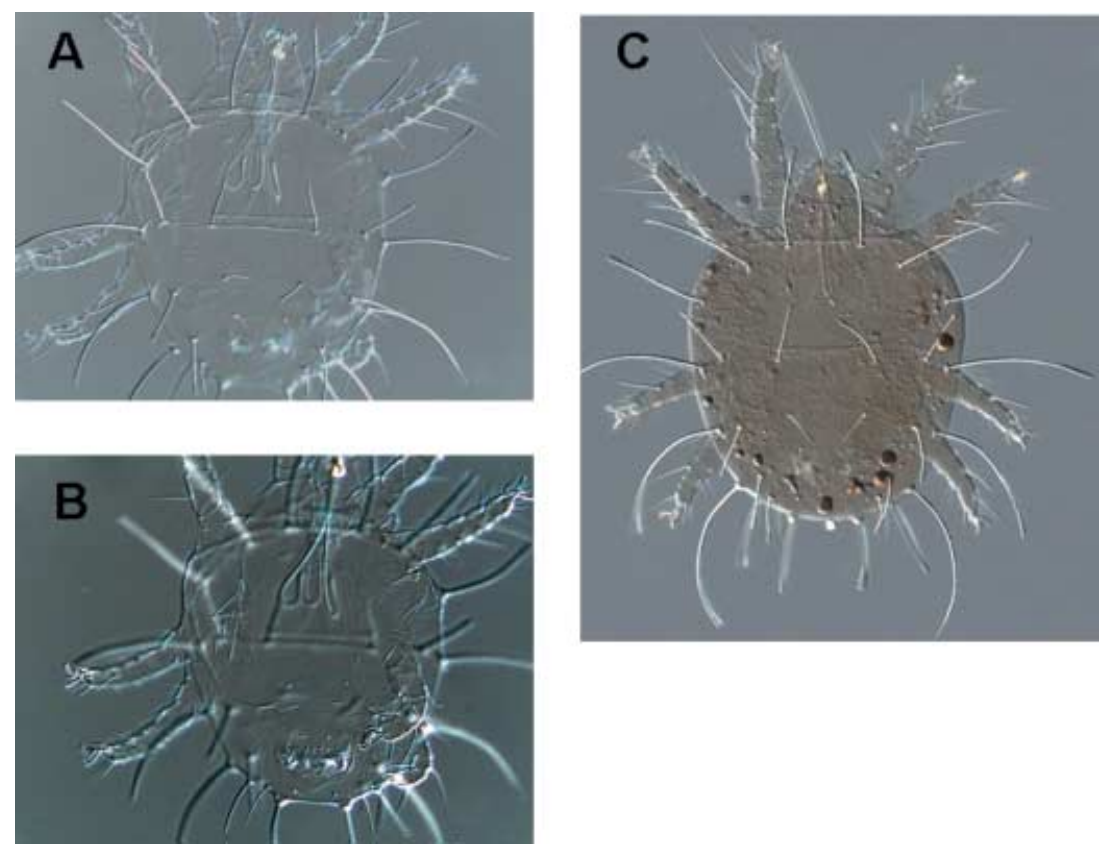

Fig. 1 Raioella indica morphological vouchers: (A) extracted for $4 \mathrm{~h}$, dorsal view; (B) same specimen, ventral view; (C) unextracted control. effects on the terrestrial arthropods studied here ranged from slight discoloration to slight-to-moderate distortion of surface features.

The diagnostic shapes of the dorsal setae and other characteristics of Raoiella indica were readily observable in the extracted specimens (Fig. 1). Spider genitalia are in most cases highly sclerotized and thus resistant to most chemical treatments: our DNA extraction protocol had no visible effect on the morphology of the female genitalia of Mecynogea lemniscata (Fig. 2), but did leave a flocculent precipitate on most of the specimens (Fig. 2A). This precipitate could be removed manually, but might pose a problem for some kinds of morphological research, such as examination of spinneret spigots (which typically are not species-specific).

In Coleomegilla maculata, the cuticle became more translucent, lost the saturated red or pink tones, and tended to brown after extraction (Fig. 3A, B). However, the black pigment that forms the dorsal maculae seems to be quite stable, so that the colour pattern could be easily assessed even in the specimens that underwent $4 \mathrm{~h}$ of extraction (not shown), and distinguished from those of Naemia sp. (Fig. 3B, C). After DNA extraction, the claw of C. maculata was sometimes more flaccid, but still clearly exhibited the diagnostic large quadrate tooth (Fig. 3D, E). Generally, the pronotal shape was not altered by extraction, with the exception of one of the 4-h specimens, where the disk buckled (not shown). The thick portions of the legs retained their shape well, but the narrow last tarsal segment sometimes became droopy. Problems with structural integrity could be minimized by placing the specimen on its back to prevent the abdomen from folding down, and carefully positioning key structures and providing tem-

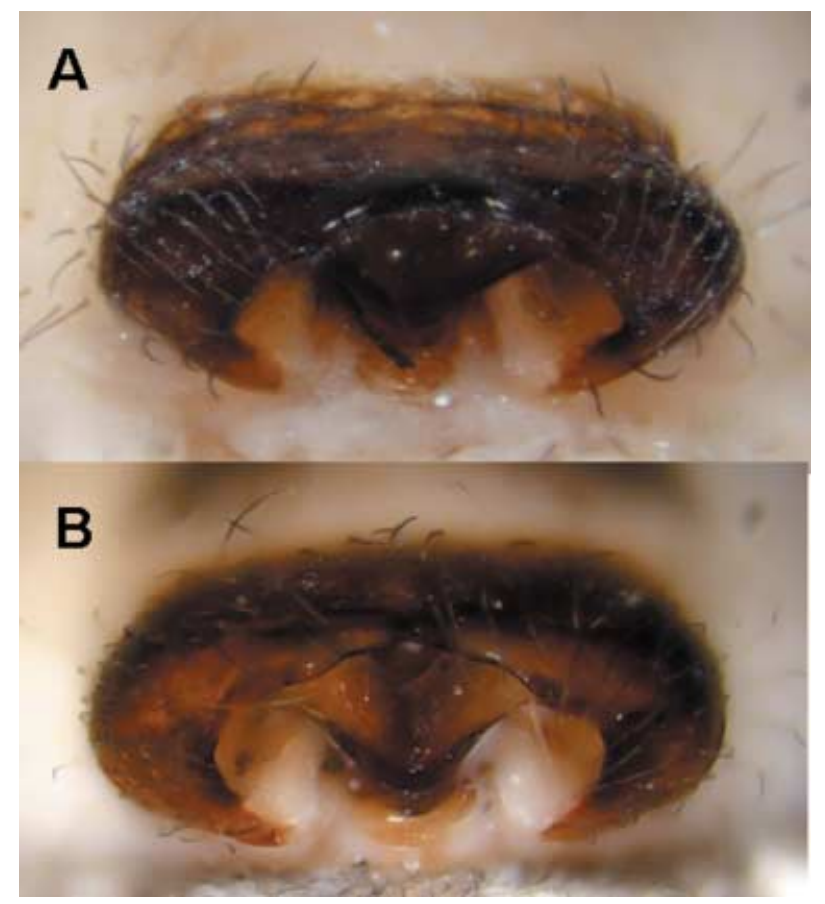

Fig. 2 Mecynogea lemniscata morphological vouchers: (A) epigynum extracted $4 \mathrm{~h}$; (B) unextracted control epigynum.

porary support until dry. Limiting extraction time to $1 \mathrm{~h}$ decreased the severity of this effect.

There was no visible effect of the extraction on colour pattern or cuticular structures of Delphinia picta (Fig. 4); genitalic morphology was also not affected (not shown). Specimens that were dried after extraction using critical 


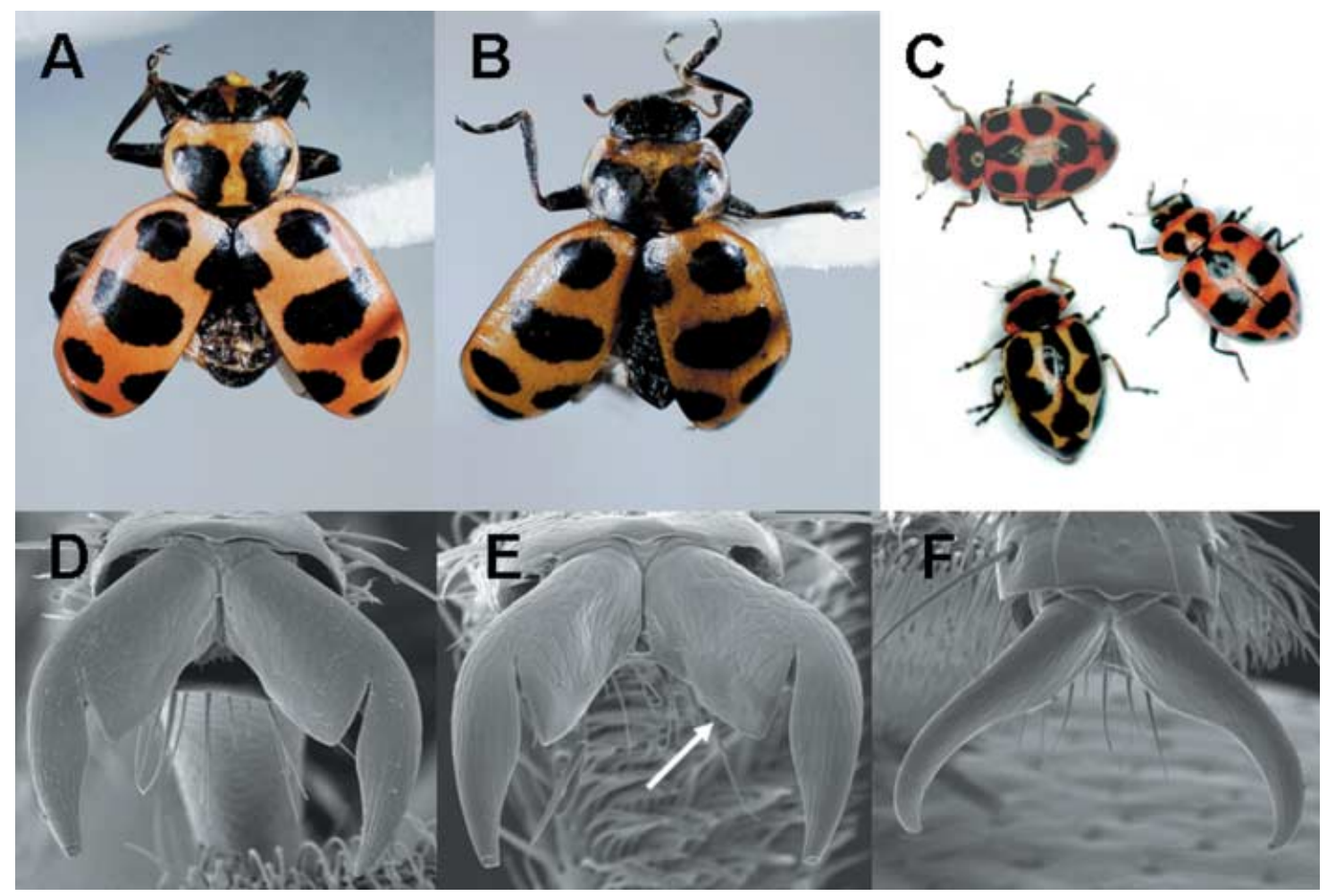

Fig. 3 Coleomegilla maculata morphological vouchers and related taxa. Top, pinned and live specimens; bottom, scanning electron micrographs of anterior tarsomere showing shape of claw. (A) pointed unextracted C. maculata control; (B) pointed C. maculata extracted for 2 h; (C) group of three live beetles: Naemia seriata from Maryland (bottom), C. maculata from Maryland (middle right), Naemia sp. from Nova Scotia (top); (D) unextracted C. maculata control; (E) C. maculata extracted for $1 \mathrm{~h}$; arrow, quadrate tooth; (F) unextracted N. seriata from Maryland.

point drying or after transfer from alcohol to ethyl acetate shrivelled to varying degrees (Fig. 4A, B), somewhat less in the critical-point-dried material. In some cases, this limited the study of chaetotaxy and colour and microtrichial patterns of various parts of the body, particularly the thorax. Extracted specimens often were unevenly covered with a powdery whitish precipitate that sometimes partially obscured surface features. This sometimes made it difficult to observe microtrichia patterns or other surface characters. The wings of the D. picta specimens were virtually indistinguishable regardless of treatment (Fig. 4D-F).

Eurytoma rhois exhibited setae that were slightly lighter in colour than the control after dehydration but prior to SEM. The key diagnostic features for E. rhois, relative sizes of sclerites and propodeal surface sculpture, were little affected by the DNA extraction process. The extracted specimen pictured, a male, had matted antennal setation (Fig. 5B). Setation on extracted material generally appeared to be abraded more easily (compare controls vs. extracted mesosoma and head, Fig. 5C, D, G, H). We do not know whether these setation artefacts were a direct result of the extraction or might be due to the transferral of extraction buffer into and out of the extraction tube.
Gels containing the amplified 421 and $488 \mathrm{bp}$ PCR products from all specimens used in the study are shown in Fig. 6 (the 1070-bp M. lemniscata amplicons, used for sequencing, are not shown but gave similar results). Almost all D. picta and C. maculata specimens produced PCR products regardless of extraction time. M. lemniscata specimens were most effectively extracted after 2-4 h extraction, while $R$. indica and E. rhois tended to require the full $4 \mathrm{~h}$ for effective extraction.

Overall, our extraction protocol yielded DNA suitable for sequencing, with effects on the extracted carcass ranging from slight discoloration to slight-to-moderate distortion of surface features that did not prevent identification as to species and effective presentation as morphological vouchers. The flocculent precipitate noted on the Mecynogea and Delphinia specimens might be removed by more assiduous rinsing of the specimens following extraction. Other so-called nondestructive DNA extraction protocols have required breaches of the cuticle ranging from pin-pricks (Phillips \& Simon 1995; Favret 2005) to amputation (Stark \& Peters 2002) and even decapitation (Johnson et al. 2001) or more extensive disarticulation, slicing, and injection (Knölke et al. 2005; Barr \& McPheron 2006). Although these 

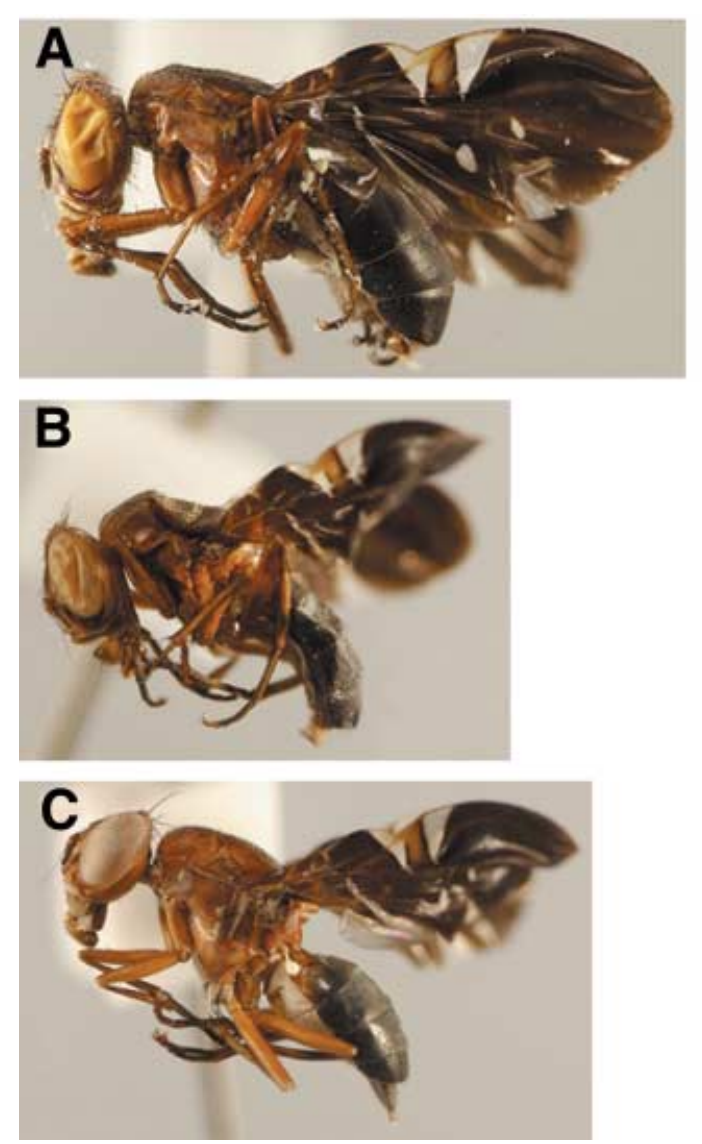
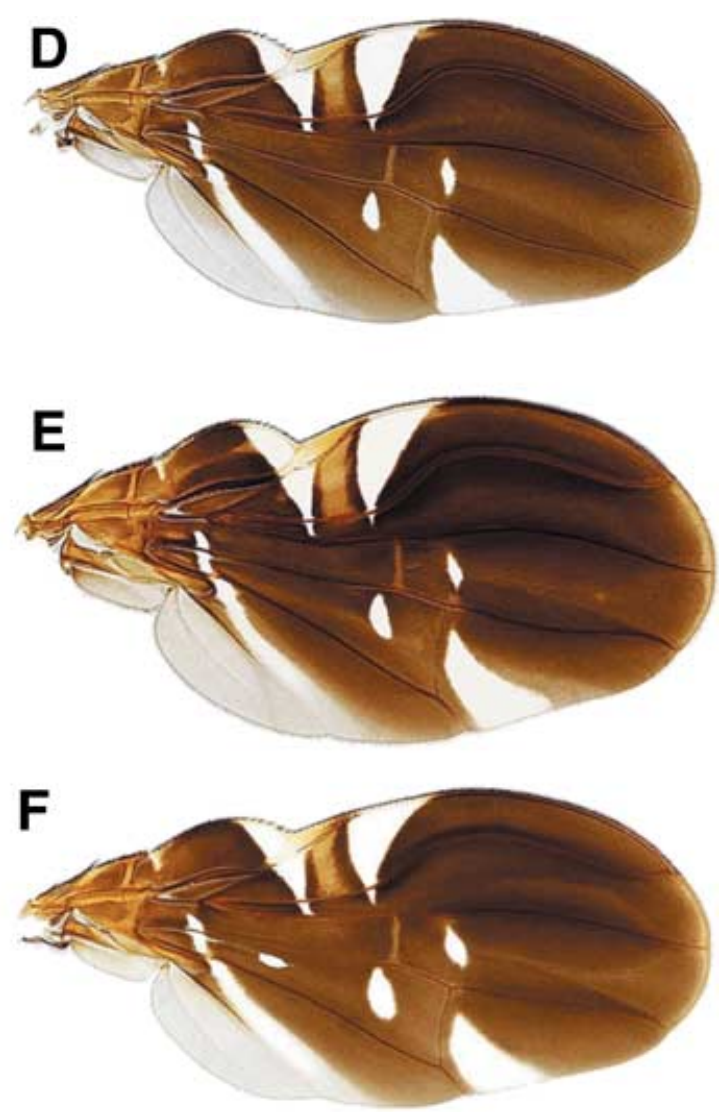

Fig. 4 Delphinia picta morphological vouchers: (A) extracted for $2 \mathrm{~h}$ and critical-point-dried; (B) extracted for $2 \mathrm{~h}$ and ethyl acetate-dried; (C) unextracted control; (D) wing extracted for $1 \mathrm{~h}$; (E) wing extracted for $4 \mathrm{~h}$; (F) wing of unextracted control; (E) and (F) were air-dried after dehydration in ethyl acetate.

protocols may provide useable vouchers, they are more tedious and labour-intensive than our procedure, which requires only soaking the specimen in buffer. They also create opportunities for cross-contamination via the piercing or cutting instrument and, if structures that have been separated for extraction are rejoined in the voucher specimen, for creation of chimaeric morphological vouchers.

Cytochrome oxidase I is an effective barcoding sequence for arachnids and insects (Barrett \& Hebert 2005; Greenstone et al. 2005). However, other genomic regions, including nuclear as well as mitochondrial sequences, have also proven useful for separating closely related arthropod taxa (Besansky et al. 1997; Chen et al. 2000, 2006; Gleeson et al. 2000; Bull et al. 2006; Greenstone 2006) and may therefore be used, by definition, as barcodes. Although we examined only mitochondrial sequences, there is no a priori reason not to expect our DNA extraction technique to be effective in extracting nuclear sequences as well.

Ongoing research on different preservation methods (e.g. Paabo et al. 2004; Mulligan 2005) may lead to protocols that cause less distortion, leaving more photogenic morphological vouchers following DNA extraction. In the meantime, use of our protocol to extract a series of specimens from 1 to $4 \mathrm{~h}$ should provide a number of individuals for which sequenceable DNA can be linked to a presentable morphological voucher. Optimized protocols would make joint vouchering of morphological specimens and the DNA extracted from them a routine part of DNA barcoding. This, coupled with hot-linked databases like MorphBank and GenBank, will improve the reliability and utility of barcoding by making it possible to view all pertinent attributes of a specimen - morphology, taxonomy, DNA sequence, voucher identity, and collection data - available simultaneously.

\section{Acknowledgements}

We are indebted to the many colleagues who supported this research. For collecting, we thank Guy Mathurian (Ministry of Agriculture, Forestry and Fisheries, Saint Lucia) for R. indica; Alex Greenstone for M. lemniscata; Julie Orr (USDA-APHIS) for D. picta; Christopher Majka (Nova Scotia Museum of Natural History) and Blake Maybank (Canadian Birding Tours), and Warren Steiner (US National Museum of Natural History), for N. seriata from Nova Scotia and Maryland, respectively; and Charles Gates 

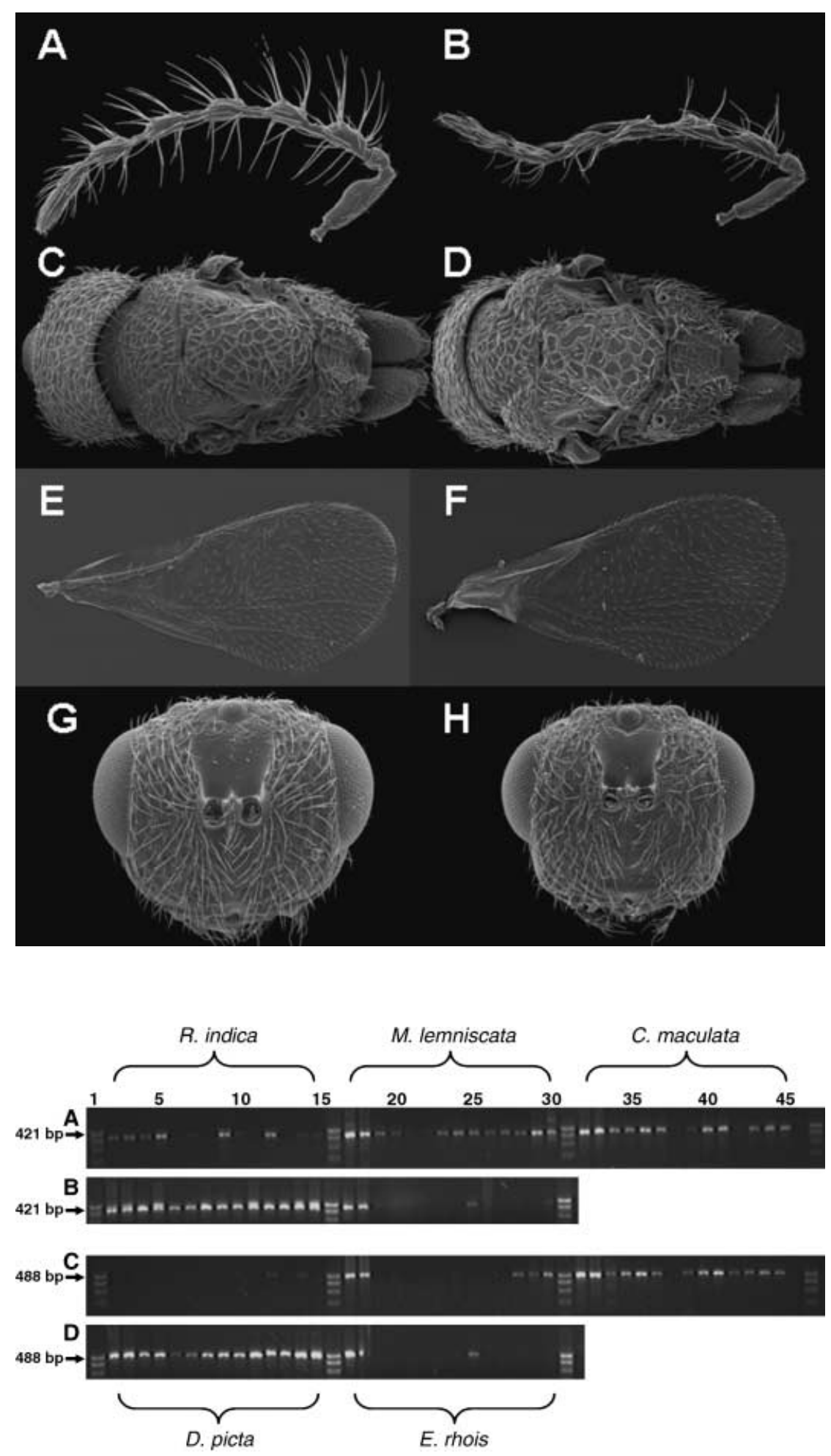

Fig. 5 Eurytoma rhois morphological voucher. Unextracted control, left; extracted for $4 \mathrm{~h}$, right. $\mathrm{A}$ and $\mathrm{B}$, antenna; $\mathrm{C}$ and $\mathrm{D}$, mesosoma; $\mathrm{E}$ and $\mathrm{F}$, forewing; $\mathrm{G}$ and $\mathrm{H}$, head.
(Warwick, RI) for E. rhois. We also thank Nit Maliku (USDAAgricultural Research Service) for preparing the mite specimens; Jeffrey Chiu, Lisa Roberts (USDA-ARS), and Scott Whittaker (NMNH) for SEM access and for preparing stubs and sputter-coating specimens; Lucrecia Rodriguez (USDA-ARS) for preparing
Delphinia images; Eugenia Okonski and Ted Schultz (NMNH) for advice and assistance with vouchering the specimens; Katja Sellman for assistance with navigating MorphBank; and Cathy Aime and Gary Miller (USDA-ARS) and two anonymous referees for valuable comments on the manuscript.
Fig. $6421 \mathrm{bp}$ (A and B) and $488 \mathrm{bp}$ ( $\mathrm{C}$ and D) gels. Lanes 1, 16, 31, and 47, $100 \mathrm{bp}$ ladder. Lane 46, no-DNA control. For A and C, lanes 2-15, Raioella indica; lanes 17-30, Mecynogea lemniscata; lanes 32-45, Coleomegilla maculata. For (B and D), lanes 2-15, Delphinia picta; lanes 17-30, Eurytoma rhois. For each species, the first two lanes are conventionally extracted DNA, the next four wells are 1-h extractions, the following four wells are 2-h extractions, and the last four wells are 4-h extractions. 


\section{References}

Aguiar AP, Sharkov A (1997) Blue pan traps as a potential method for collecting Stephanidae (Hymenoptera). Journal of Hymenoptera Research, 6, 422-423.

Anderson NM, Cheng L, Damgaard J, Sperling FAH (2000) Mitochondrial DNA sequence variation and phylogeography of oceanic insects (Hemiptera: Gerridae: Halobates spp.). Marine Biology, 136, 421-430.

Armstrong KF, Ball SL (2005) DNA barcodes for biosecurity: invasive species identification. Philosophical Transactions of the Royal Society of London. Series B, Biological Sciences, 360, 1813-1823.

Ball SL, Armstrong KF (2006) DNA barcodes for pest identification: a test case with tussock moths (Lepidoptera: Lymnatriidae). Canadian Journal of Forest Research, 36, 337-350.

Ball SL, Hebert PDN, Burian SK, Webb JM (2005) Biological identifications of mayflies (Ephemeroptera) using DNA barcodes. Journal of the North American Benthological Society, 24, 508-524.

Barber P, Boyce SL (2006) Estimating diversity of Indo-Pacific coral reef stomatopods through DNA barcoding of stomatopod larvae. Proceedings of the Royal Society of London. Series B, Biological Sciences, 273, 2053-2061.

Barr NB, McPheron BA (2006) Molecular phylogenetics of the genus Ceratitis (Diptera: Tephritidae). Molecular Phylogenetics and Evolution, 38, 216-230.

Barrett DH, Hebert PDN (2005) Identifying spiders through DNA barcodes. Canadian Journal of Zoology, 83, 481-491.

Benson DA, Karsch-Mizrachi I, Lipman DJ, Ostell J, Wheeler DL (2007) GenBank. Nucleic Acids Research, 35, 21-25.

Besansky NJ, Lohman T, Fahey GT et al. (1997) Patterns of mitochondrial variation within and between African malaria vectors, Anopheles gambiae and An. arabiensis, suggest extensive gene flow. Genetics, 147, 1817-1828.

Besansky NJ, Severson DW, Ferdig MT (2003) DNA barcoding of parasites and invertebrate disease vectors: what you don't know can hurt you. Trends in Parasitology, 19, 545-546.

Brower AVZ (1999) A new mimetic species of Heliconius (Lepidoptera: Nymphalidae), from southeastern Colombia, as revealed by cladistic analysis of mitochondrial DNA sequences. Zoological Journal of the Linnean Society, 116, 317-332.

Brunner PC, Fleming C, Frey JE (2002) A molecular identification key for economically important thrips species (Thysanoptera: Thripidae) using direct sequencing and a PCR-RFLP approach. Agricultural and Forest Entomology, 4, 127-136.

Bull V, Beltrán M, Jiggins CD, McMillan WO, Bermingham E, Mallet J (2006) Polyphyly and gene flow between non-sibling Heliconius species. BMC Biology, 4, 11.

Chen Y, Giles KL, Greenstone MH (2002) Molecular evidence for a species complex in the genus Aphelinus (Hymenoptera: Aphelinidae). Annals of the Entomological Society of America, 95, 29-34.

Chen Y, Giles KL, Payton ME, Greenstone MH (2000) Identifying key cereal aphid predators by molecular gut analysis. Molecular Ecology, 9, 1887-1898.

Chen Y, Pike K, Greenstone MH, Shufran KA (2006) Molecular markers for identification of the hyperparasitoids Dendrocerus carpenteri and Alloxysta xanthopsis. Lysiphlebus testaceipes parasitizing cereal aphids. BioControl, 51, 183-194.

Cockburn AF (1990) A simple and rapid technique for identification of large numbers of individual mosquitoes using DNA hybridization. Archives of Insect Biochemistry and Physiology, 14, 191-199.
De Ley P, De Ley TD, Morris Ket al. (2005) An integrated approach to fast and informative morphological vouchering of nematodes for applications in molecular barcoding. Philosophical Transactions of the Royal Society of London. Series B, Biological Sciences, 360, 1945-1958.

Favret C (2005) A new non-destructive DNA extraction and specimen clearing technique for aphids (Hemiptera). Proceedings of the Entomological Society of Washington, 107, 469-470.

Flechtmann CHW, Etienne J (2004) The red palm mite, Raoiella indica Hirst, a threat to palms in the Americas (Acari: Prostigmata: Tenuipalpidae). Systematic and Applied Acarology, 9, 109-110.

Gleeson D, Holder P, Newcomb R, Howitt R, Dugdale J (2000) Molecular phylogenetics of leafrollers: applications to DNA diagnostics. New Zealand Plant Protection, 53, 157-162.

Greenstone MH (2006) Molecular methods for assessing insect parasitism. Bulletin of Entomological Research, 96, 1-13.

Greenstone MH, Rowley DL, Heimbach U, Lundgren JG, Pfannenstiel RA, Rehner SA (2005) Barcoding generalist predators by polymerase chain reaction: carabids and spiders. Molecular Ecology, 14, 3247-3266.

Greenstone MH, Rowley DR, Weber DC, Hawthorne DJ (2007) Feeding mode and prey detectability half-lives in molecular gut-content analysis: An example with two predators of the Colorado potato beetle. Bulletin of Entomological Research, 97, 201-209.

Grosjean S, Thomas M, Glaw F, Vences M (2006) The tadpole of the Malagasy treefrog Bophis rufioculis: molecular identification and description. Spixiana, 29, 73-76.

Hafner MS (1994) Reply: molecular extracts from museum specimens can - and should - be saved. Molecular Phylogenetics and Evolution, 3, 270-271.

Hajibabael M, Janzen DH, Burns JM, Wallachs W, Hebert PDN (2006) DNA barcodes distinguish species of Lepidoptera. Proceedings of the National Academy of Sciences, USA, 103, 968-971.

Harris DJ (2003) Can you bank on GenBank? Trends in Ecology $\mathcal{E}$ Evolution, 18, 317-319.

Hebert PDN, Cywinska A, Ball SL, deWaard JR (2002) Biological identifications through DNA barcodes. Proceedings of the Royal Society of London. Series B, Biological Sciences, 270, 313-322.

Hedin MC, Maddison WP (2001) A combined molecular phylogeny approach to phylogeny of the jumping spider subfamily Dendryphantinae (Araneae: Salticidae). Molecular Phylogenetics and Evolution, 18, 386-403.

Heraty J, Hawks D (1998) Hexamethyldisilazane - a chemical alternative for drying insects. Entomological News, 109, 369-374.

Hogg ID, Hebert PDN (2005) Biological identification of springtails (Hexapoda: Collembola) from the Canadian Arctic, using mitochondrial DNA barcodes. Canadian Journal of Zoology, 82, 749-754.

Jarman SN, Gales NJ, Tierny M, Gill PC, Elliott NG (2002) A DNA-based method for identification of krill species and its application to analyzing the diet of marine vertebrate predators. Molecular Ecology, 11, 2679-2690.

Jeppson LR, Keifer HH, Baker EW (1975) Mites Injurious to Economic Plants. University of California Press, Berkeley.

Johnson KP, Adams RJ, Clayton DH (2001) Molecular systematics of goniodidae (Insecta: Phthiraptera). Journal of Parasitology, 87, 862-869.

Kaila L, Ståhls G (2006) DNA barcodes: evaluating the potential of COI to differentiate closely related species of Elachista (Lepidoptera: Gelechioidae: Elachistidae) from Australia. Zootaxa, 1170, $1-26$. 
Knölke S, Erlacher S, Huasmann A, Miller MA, Segerer AH (2005) A procedure for combined genitalia dissection and DNA extraction in Lepidoptera. Insect Systematics \& Evolution, 35, 401-409.

Levi HW (1980) The orb-weaver genus Mecynogea, the subfamily Metinae and the genera Pachygnatha, Glenognatha, and Azilia of the subfamily Tetragnathinae north of Mexico (Araneae: Araneidae). Bulletin of the Museum of Comparative Zoology, 149, 175.

Mitchell A, McClay AS, Pohl GR, Sperling FAH (2005) PCR-based methods for identification of two Eteobalea species (Lepidoptera: Cosmopterigidae) used as biocontrol agents of weedy Linaria species (Scrophulariaceae). Canadian Entomologist, 137, 129-137.

Monoghan MT, Balke M, Gregory TR, Vogler AP (2005) DNA-based species delineation in tropical beetles using mitochondrial and nuclear markers. Philosophical Transactions of the Royal Society of London. Series B, Biological Sciences B, 360, 1925-1933.

Mulligan CJ (2005) Isolation and analysis of DNA from archaeological, clinical and natural history specimens. Methods in Enzymology, 395, 87-103.

Noyes J (1998) A study of five methods of sampling Hymenoptera (Insecta) in a tropical rainforest, with special reference to the Parasitica. Journal of Natural History, 23, 285-298.

Paabo S, Poinar H, Serre D et al. (2004) Genetic analysis from ancient DNA. Annual Review of Genetics, 38, 645-679.

Paskewitz SM, Collins FH (1990) Use of the polymerase chain reaction to identify mosquito species of the Anopheles gambiae complex. Medical and Veterinary Entomology, 4, 367-373.

Phillips AJ, Simon C (1995) Simple, efficient, and nondestructive DNA extraction protocol for arthropods. Annals of the Entomological Society of America, 88, 281-283.

Platnick NI (2006) The World Spider Catalog, Version 7.0.

Rohland N, Siedel H, Hofreiter M (2004) Nondestructive DNA extraction method for mitochondrial DNA analysis of museum specimens. Biotechniques, 36, 814-821.

Simon C, Frati F, Beckenbach A, Crespi B, Liu H, Flook P (1994) Evolution, weighting, and phylogenetic utility of mitochondrial gene sequences and a compilation of conserved polymerase chain reaction primers. Annals of the Entomological Society of America, 87, 651-701.

Sperling FAH, Hickey DA (1994) Mitochondrial DNA sequence variation in the spruce budworm species complex (Choristoneura: Lepidoptera). Molecular Biology and Evolution, 11, 656-665.

Starks PT, Peters JM (2002) Semi-nondestructive genetic sampling from live eusocial wasps, Polistes dominulus and Polistes fuscus. Insectes Sociaux, 49, 20-22.

Thomas RH (1994) Molecules, museums and vouchers. Trends in Ecology \& Evolution, 9, 413-414.

Toft S (1983) On identifying juvenile spiders: some general considerations and an example (genus Meta) (Arachnida: Araneae). Verhandlungen Des Naturwissenschaftlichen Vereins in Hamburg, 26, 211-216.

Triplehorn CA, Johnson NF (2004) Borror and Delong's Introduction to the Study of Insects, 7th edn. Thomson Brooks, Cole, Belmont, California.

United States Department of Agriculture (1986) Insects and mites: techniques for collection and preservation. Agricultural Research Service, Miscellaneous Publication No. 1443.

Vigalys R (2003) Taxonomic misidentification in public DNA databases. New Phytologist, 160, 4-5.

Wells JD, Sperling FAH (2001) DNA-based identification of forensically important Chrysomyinae (Diptera: Calliphoridae). Forensic Science Internation, 120, 110-115.

Whitfield JB, Cameron SA (1994) Museum policies concerning specimen loans for molecular systematic research. Molecular Phylogenetics and Evolution, 3, 268-269.

This study is the result of collaborative research on natural enemy-pest interactions in agroecosystems, led by Matthew Greenstone. The research was made possible by Daniel Rowley's skills in Molecular Biology and the other authors' expertise in systematics and taxonomy of the exemplary taxa: Acari (Ronald Ochoa); Araneae (Jonathan Coddington); Coleoptera (Natalia Vandenberg); Diptera (Allen Norrbom); and Hymenoptera (Michael Gates). 